Review

\title{
Towards Circulating-Tumor DNA-Based Precision Medicine
}

\author{
Ai Hironaka-Mitsuhashi ${ }^{1, *}$, Anna Sanchez Calle ${ }^{1}$, Takahiro Ochiya ${ }^{1,2}$, Shin Takayama ${ }^{3}$ and \\ Akihiko Suto ${ }^{3}$ iD \\ 1 Division of Molecular and Cellular Medicine, National Cancer Centre Research Institute, 5-1-1 Tsukiji, \\ Chuo-ku, Tokyo 104-0045, Japan \\ 2 Department of Molecular and Cellular Medicine, Institute of Medical Science, Tokyo Medical University, \\ 6-7-1 Nishishinjuku, Shinjuku-ku, Tokyo 160-0023, Japan \\ 3 Department of Breast Surgery, National Cancer Centre Hospital, 5-1-1 Tsukiji, Chuo-ku, \\ Tokyo 104-0045, Japan \\ * Correspondence: ahironak@ncc.go.jp; Tel.: +81-3-3542-2511; Fax: +81-3-3542-2511
}

Received: 2 July 2019; Accepted: 22 August 2019; Published: 2 September 2019

\begin{abstract}
In the era of precision medicine, targeted therapies have been implemented for various diseases. Genomic information guides decision-making in cancer treatment. The improvements in next-generation sequencing and polymerase chain reaction have made it possible to access the genetic information using circulating-tumor DNAs (ctDNAs). Molecular characteristics of individual tumors can be obtained by analysis of ctDNAs, thus making them excellent tools to guide decision-making during treatment. In oncology, the use of ctDNAs in clinical practice is now gaining importance. Molecular analysis of ctDNAs has potential for multiple clinical applications, including early diagnosis, prognosis of disease, prognostic and/or predictive biomarkers, and monitoring response to therapy and clonal evolution. In this paper, we highlight the applications of ctDNAs in cancer management, especially in metastatic setting, and summarize recent studies about the use of ctDNAs as predictive biomarkers for the therapeutic adaptation/response in lung cancer, breast cancer, and colorectal cancer. These studies offer the evidence to use ctDNAs as a promising approach to solve unmet clinical needs.
\end{abstract}

Keywords: biomarker; breast cancer; circulating-tumor DNA; colorectal cancer; lung cancer; precision medicine; targeted therapy

\section{Introduction}

Precision medicine is an emerging approach for both prevention and treatment of disease [1-3]. It is important to develop more precise diagnostic tools in precision medicine for a variety of diseases including cancer. In oncology, precision medicine aims to select effective treatment based on the molecular characteristics of individual tumors. Genomic information is important for treatment strategy, since targeted therapy is directed against key signaling pathways involved in cancer growth and malignant progression [4-14]. Recently, improvements in the next-generation sequencing (NGS) and polymerase chain reaction (PCR)-based approaches have enabled the identification of genomic information by using biomarkers such as circulating tumor cells, cell-free DNAs (cfDNAs), circulating RNA including mRNA and secreted microRNAs in peripheral blood, and other body fluids, collectively termed liquid biopsies [15-20]. Applications of liquid biopsy include early diagnosis, prognosis of disease, prognostic and/or predictive biomarkers for the therapeutic adaptation/response, and monitoring response to therapy and clonal evolution.

Among liquid biopsies, cfDNAs are of particular interest $[19,21,22]$. The first publication on the presence of cell-free nucleic acid in the blood of healthy individuals was attributed to Mandel et al. in 
1948 [23]. The next impressive study was the report published in 1977 that demonstrated increasing levels of cfDNAs in the blood of cancer patients in comparison with healthy individuals [24]. Molecular analysis of cfDNAs has been actively researched in cancer management since previous studies confirmed that elevated levels of cfDNAs were detected in various kinds of solid tumors regardless of tumor progression [25]. As cancer progresses, the levels of cfDNAs increase and cfDNAs from tumor cells are likely to have genomic alterations corresponding to the tumor tissues [25-36]. Since cfDNAs can be an alternative to the tumor tissue, their utility has been exploited in the management of cancer, especially for lung cancer, breast cancer, and colorectal cancer (Figure 1).

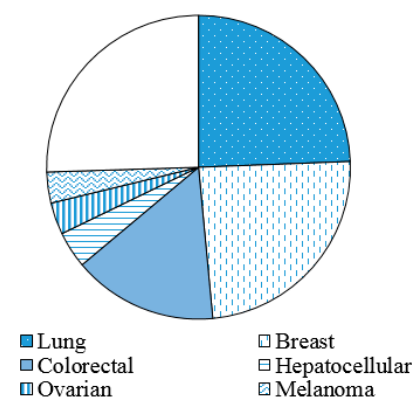

Figure 1. Proportion of the publication numbers reporting the use of circulating DNA in cancer types. This is a modification of Figure 4 in Reference [21], web of science citation reports showing 5800 records for the cancer circulating DNA up to the end of 2018. The most studied cancer subtypes are lung cancer, breast cancer, and colorectal cancer, in that order.

On the other hand, the actual mechanism of secretion of cfDNAs has not yet been elucidated [17]. At present, cfDNAs are thought to be released from cells, mostly through apoptosis and necrosis, and possibly also by active secretion $[19,37]$. In this review, we use the term circulating-tumor DNAs (ctDNAs) instead of cfDNAs since we focused on circulating DNA fragments directly derived from tumor cells. In oncology, the use of ctDNAs in clinical practice for diagnosis/prognosis is gaining importance. For instance, EGFR (epidermal growth factor receptor) mutation testing using ctDNAs was approved as a companion in vitro diagnostic, while ctDNA testing has been required for the pre-analytical and analytical phase in the other cancer [38-40]. The approval of molecular analysis of cfDNAs should open the door for the approval of other tests, not only for the prediction of therapeutic responses, but also to monitor tumor burden [21]. In our review, we will highlight the applications of cfDNAs in cancer management (Figure 2), especially in a metastatic setting, and summarize recent studies about use of cfDNAs as promising biomarkers for lung cancer, breast cancer, and colorectal cancer. These studies offer evidence in favor of cfDNAs to be used as reliable tools to solve unmet clinical needs.

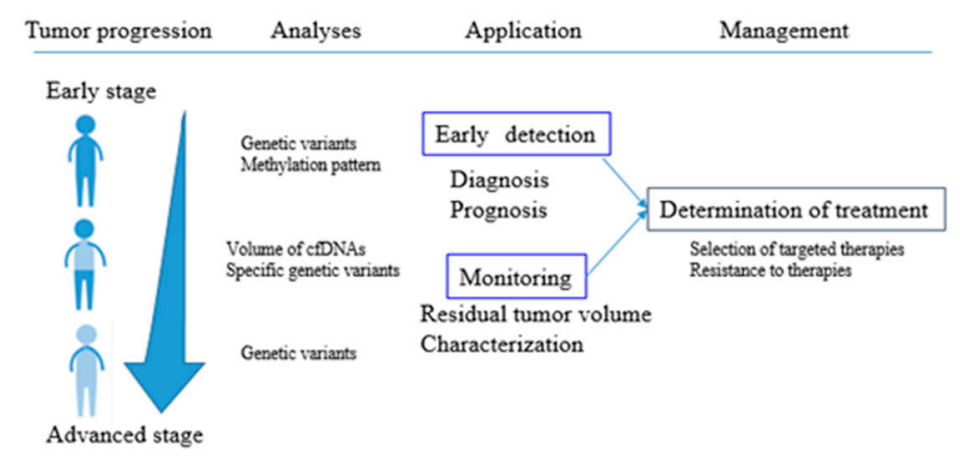

Figure 2. ctDNAs as promising biomarkers in the different phases of cancer progression. The schematic summarizes the most suitable clinical applications in each phase. In early stage, genetic variants and methylation patterns of ctDNAs might be useful for early diagnosis. Relevant prognostic 
information can be provided by analysis of genetic variants of ctDNAs. In particular, specific genetic alterations and the volume of ctDNAs can be used for the detection of the minimal residual disease. In metastatic setting, analysis of ctDNAs might be an alternative to tissue analysis for the identification of predictive biomarkers for the therapeutic adaptation/response. This schema suggests its clinical application to guide decision-making in cancer treatment.

\section{2. ctDNAs Are Promising Biomarkers in Oncology}

ctDNAs can be advantageous among liquid biopsies owing to improvements in sensitivity of the techniques to capture ctDNAs. The ctDNAs are at low levels in cfDNAs, and thus highly sensitive technologies are required for their detection $[17,27,41]$. The presence of specific mutations in cancer helps to distinguish ctDNAs from normal cfDNAs. At present, digital-PCR has enabled the detection of rare mutations in cfDNAs with allele fractions as low as $0.001 \%$ in a wild-type background [42]. NGS provides simultaneous characterization of somatic mutations such as single-nucleotide variants, insertions/deletions, structural rearrangements, and copy-number alterations. Aside from mutational alteration, epigenetic alterations such as methylation of promoter/enhancer can be measured by using ctDNAs. The increasing availability and reliability of these techniques has been facilitating novel, high-sensitivity applications for ctDNAs [19]. It has been reported that molecular analysis of ctDNAs can guide treatment decision, however, ctDNA concentration values are biased in the literature, since in most cases, ctDNAs are determined from mutations of a few or a panel of genes $[12,16,17,19,21,26,29,43-45]$.

Genomic information decides adaptations for targeted therapy. Examples of targeted therapies include amplification of human epidermal growth factor receptor2 (HER2) for HER2 antibody in breast cancer and in gastric cancer and activating EGFR mutations for EGFR tyrosine kinase inhibitors (TKIs) in non-small cell lung cancer (NSCLC) $[5,11,13,38,46,47]$. In metastatic colorectal cancer (mCRC), KRAS proto-oncogene, GTPase (KRAS) mutation is responsible for primary resistance to EGFR blockage [6-9]. Genotyping of tumors is recommended as routine practice in clinical oncology. While tissue biopsy is the gold-standard for genotyping, the feasibility of genotyping of ctDNAs in various kinds of cancer has been demonstrated [36,48-50].

An advantage of ctDNA testing compared with a tissue biopsy is that it is less invasive and allows sequential blood sampling. In a metastatic setting, ctDNAs are better diagnostic samples than single-site biopsied tissue since ctDNAs originate from multiple tumor sites $[16,17,25,30,51]$. For example, in the diagnosis of lung cancer, the lack of available tissues for molecular profiling, inaccessible tumor location, and the risk of complications in case of adverse events with image-guided biopsies are serious limitations for a tissue biopsy [52]. Delays often occur in tissue biopsy. In a prospective study of EGFR genotyping in advanced lung cancer, the median test turnaround time for tissue biopsy was 12 (1-53) days for a new diagnosis of non-squamous, non-small cell lung cancer. In contrast, the median time was $3(1-7)$ days for ctDNA testing for the same [53]. ctDNA testing is cost effective as compared to tissue biopsy, which has the added risk of complications [52].

The alteration of ctDNAs reflect real time information which occurs in vivo. The half-life of ctDNAs in circulation has been estimated to be between $16 \mathrm{~min}$ and $2.5 \mathrm{~h}$ [19]. It has been reported that ctDNAs are ideal biomarkers to monitor response to therapy and emergence of secondary mutations associated with resistance to therapy, revealing heterogeneity and clonal evolution in cancer progression $[12,16,25,26,29,39,40,45,51,54-78]$. Thus, ctDNA testing is an appealing approach for the genotyping of individual tumors. Quantitative and molecular analysis of ctDNAs enables assessment of the dynamic changes like a 'real-time' snapshot of the disease. 


\section{Use of ctDNAs in Cancer Management}

\subsection{Lung Cancer}

EGFR mutations are commonly observed in NSCLC and present in almost $50 \%$ of patients with advanced NSCLC [79,80]. Activating EGFR mutations are mainly the exon 19 deletions (Del19) and the L858R point mutation in exon 21, which are known to be the most important predictive factors for sensitivity to EGFR TKIs and are used for selection of EGFR TKIs in NSCLC [5,81]. First-generation TKIs, such as erlotinib and gefitinib, target the receptor via reversible binding of tyrosine kinase domain, while second-generation TKIs, such as afatinib, covalently bind the target [70]. Response and progression-free survival (PFS) with EGFR TKIs are superior to standard chemotherapy in NSCLC with activating EGFR mutations $[39,46]$. Detection of activating EGFR mutations for NSCLC by ctDNA testing shows high concordance with those by tissue biopsy, especially in specificity $[39,40,49,53,60,65,82-86]$. A meta-analysis examining 27 studies conducted between the years 2007 and 2015 demonstrated a pooled sensitivity of 0.62 (95\% confidence intervals (CI), 0.51-0.72) and 0.96 (95\% CI 0.93-0.98) for specificity in EGFR genotyping in NSCLC [49]. While tissue biopsy often provides limited and low-quality material for genotyping at the time of progression, monitoring of active EGFR mutation is described as a potential prognostic marker for the efficacy of EGFR TKIs [39,76,78,86]. High performance of characteristics of EGFR mutation by ctDNA testing was demonstrated in a real-world setting.

The substitution of threonine to methionine at amino acid position 790 (T790M) in exon 20 of EGFR gene reduces binding of first- and second-generation EGFR TKIs to the ATP-binding pocket of EGFR, thereby reducing response. T790M mutations account for approximately $50 \%-60 \%$ of the acquired resistance mechanisms [80]. Detection of T790M mutation by ctDNA testing has proved to be challenging due to low abundance in blood before the beginning of the treatment $[87,88]$. On the other hand, it has been reported that T790M mutations by ctDNA testing are observed in the course of treatment $[59,66]$. The third generation TKIs such as rociletinib (CO-1686, previously known as AVL-301) and osimertinib (previously known as AZD9291) target both activating EGFR mutations and T790M mutations [47,67,89-91]. Osimertinib was approved for patients with acquired T790M mutations, and the detection method for acquired T790M mutation includes both a tumor-tissue biopsy and ctDNA testing while testing the tumor tissue is the recommended method. Molecular analysis of ctDNAs allowed ongoing genomic analysis for patients on third-generation TKIs [62,70,92]. For instance, C797S mutation was identified as a novel key driver of resistance to osimertinib, while L798I mutation was reported in the resistance to rociletinib [62,70]. These studies showed that ctDNA testing could reveal clonal evolution and resistance to therapies, suggesting further implementation of ctDNA testing in clinical practice for lung cancer therapy in the near future.

\subsection{Breast Cancer}

Breast cancer is a heterogeneous disease [93]. Breast cancer is clinically categorized into three major subtypes, which show distinct characteristics and reflect patient prognosis: hormone receptor (HR)-positive type (oestrogen receptor $[\mathrm{ER}]+$, progesterone receptor $[\mathrm{PgR}]+/-$, and HER2-), HER2-positive type (ER-, PgR +/-, and HER2+), and triple-negative (TN) type (ER-, PgR-, and HER2-) [94]. Interestingly, it was reported that variations of somatic mutations across molecular subtypes are observed by molecular analysis of ctDNAs [95].

Endocrine therapy (ET) for breast cancer was the first ever targeted therapy used in any type of cancer. ET-based regimens form the backbone of the treatment for HR-positive type, while anti-HER2 treatment works for HER2-positive type [13,96]. ET includes a variety of agents like selective ER modulator (e.g., tamoxifen), selective ER down-regulator (e.g., fulvestrant), and aromatase inhibitors (AIs) (e.g., exemestane, letrozole, anastrozole). Today, combinations of additional drugs to ET have been developed to overcome resistance to acquired ET, for example, phosphatidylinositol 3-kinase (PI3K) inhibitors (e.g., buparlisib, alpelisib, taselisib), mammalian target of rapamycin (mTOR) inhibitors (e.g., everolimus, temsirolimus), and cyclin-dependent kinase 4 and 6 (CDK4/6) inhibitors (e.g., palbociclib, 
ribociclib, abemacilib) [97]. However, no specific biomarkers for the use of these new agents have been identified.

AIs are the current recommended first-line choice for ET [97]. One of the mechanisms of resistance to AIs is the activating mutations in the ligand-binding domain of ESR1, the gene coding for the ER $\alpha$ [98]. While ESR1 mutations rarely occur in primary breast cancer, enrichment of ESR1 mutations is observed in metastatic breast cancer (MBC) [98,99]. Notably, ESR1 mutations (e.g., Y537C/S/N, D538G) are frequently sub-clonal with high levels of polyclonality [100-102]. Several groups observed the existence of ESR1 mutations in MBC by ctDNA testing, suggesting that ctDNAs are a good substrate for detection of ESR1 mutations [99,101-104]. On the other hand, ESR1 epigenetic silencing potentially affects response to AIs. It was reported that ESR1 methylation in ctDNAs could be a potential biomarker for response to everolimus/exemestane treatment [105]. With regards to patient outcome, it was reported that ESR1 mutations in ctDNAs are associated with inferior outcomes [106-108]. Contrary to these studies, a phase III PALOMA-3 study for the assessment of palbociclib and fluvestrant efficacy reported that prediction of clinical outcome is limited by using ESR1 mutations in plasma samples $[109,110]$.

Together with ESR1, PIK3CA, the p110 isoform of PI3K, is regarded as a promising biomarker. PIK3CA mutations are frequently observed in HR-positive MBC and are associated with activation of PI3K pathway [111]. In a phase III study that was the first randomized clinical trial involving PI3K inhibitors in MBC, detection of PIK3CA mutation by ctDNA testing showed improvement in PFS with buparlisib plus fluvestrant compared with fluvestrant alone (4.6 month vs. 1.5 month; hazard ratio (HR) $0.58,95 \%$ CI $0.32-1.05$, log-rank $p=0.036$ ), while there was no significant difference in PFS between the PI3K pathway activated group and non-activated group identified by tissue sample sequencing [112]. While prognostic value of PIK3CA has not been elucidated in ET including new developing drugs, O'Leary et al. showed that PIK3CA ctDNA levels after 15 days' treatment with palbociclib and fluvestrant strongly predicts PFS (HR 3.94, 95\% CI 1.61-9.64, log-rank $p=0.0013$ ) $[109,113]$.

HER2 amplification is a critical biomarker conferring sensitivity in combination with anti-HER2 therapy [13]. It was demonstrated that the molecular analyses of ctDNAs could reveal the existence of amplified HER2 in ctDNAs [114]. However, sensitivity for HER2 detection in ctDNAs was relatively low [114]. On the other hand, it was reported that longitudinal gene-panel ctDNA sequencing could reveal the mechanism of resistance to pyrotinib, a TKI which has been developed for HER2-positive tumors [61]. In a phase II clinical trial that aimed to assess clinical benefits of neratinib, pan HER inhibitor in HER2-mutated non-amplified MBC, ctDNA HER2 mutant variant allele frequency was predictive of response to neratinib [115].

Unfortunately, effective targeted therapy for TN breast cancer has not been investigated yet. Majority of the TN type has mutations in breast cancer susceptibility gene (BRCA) 1/2. Response and PFS with olaparib, a poly adenosine diphosphate-ribose polymerase (PARP) inhibitor, is superior to standard chemotherapy in MBC with BRCA germline mutations (7.0 month vs. 4.2 month; HR 0.58 , $95 \%$ CI $0.43-0.80, \log$-rank $p<0.001$ ) [116]. One of the mechanisms of resistance to PARP inhibitor is from somatic reversion mutations or intragenic deletions that restore the functions of BRCA [117]. It was reported that BRCA1/2 reversion mutations could be detected by ctDNA sequencing analysis in patients with ovarian and breast cancer [118].

At present, most of the studies have failed to develop workable criteria of ctDNA testing for clinical practice in MBC [61,119]. However, molecular analysis of ctDNAs is an appealing alternative approach for the characterization of tumor molecular heterogeneity and its evolving biology [22,26]. Thus, ctDNA testing may provide important clues to investigate dedicated predictive biomarkers for new drugs since a wide range of agents are being developed for MBC.

\subsection{Colorectal Cancer}

Monoclonal EGFR antibodies such as cetuximab and panitumumab are standard agents of treatment regimens for $\mathrm{mCRC}$, either alone or in combination with chemotherapy. Addition of EGFR antibodies has improved patient survival [6-9]. In clinical practice, the identification of RAS mutations 
is required before initiating treatment since RAS mutations are regarded as critical biomarkers of innate resistance to EGFR inhibitors [6]. Currently, determination of RAS mutation status is performed using formalin-fixed paraffin-embedded tumor tissues. Molecular analysis of ctDNAs can be used as an alternative to tissue analysis. A meta-analysis examining 31 studies conducted between the years 2000 and 2017 demonstrated a pooled sensitivity of 0.64 (95\% CI, 0.61-0.67) and 0.94 (95\% CI 0.93-0.96) for specificity in RAS mutations in CRC [50]. Previous studies have demonstrated RAS mutations by ctDNA testing as an early marker of therapeutic response $[34,45,120]$. In addition, the emergence and the progressive increase of detectable RAS mutations prior to subsequent progression by ctDNA testing have been demonstrated $[25,45,54,71-74]$.

A treatment strategy for patients who respond and then relapse due to resistance to EGFR inhibitors is urgently required. Most frequent secondary mutations occur in KRAS and NRAS, which are presently untreatable as the corresponding proteins are fractious to pharmacological blockage [121]. There are only very few available treatment strategies based on molecular rationale in mCRC after failure of EGFR blockage. HER2 amplification is an emerging biomarker in colorectal cancer that confers to combination anti-HER2 treatment and predicts resistance to EGFR blockage, although the frequency of HER2 amplification is relatively low. It was reported that clinically validated ctDNA testing could be a reliable diagnostic of HER2 copy number in plasma that predicted response rates to trastuzumab and lapatinib in mCRC [122]. Upon failure of chemotherapy plus EGFR antibodies, CRC patients usually stop additional EGFR antibodies, while re-challenge of EGFR antibodies could provide clinical benefits in molecularly selected patients beyond second line [123]. Interestingly, Parseghian et al. demonstrated clinical benefits of re-challenge of EGFR blockage by capturing the mutant minimal drop of RAS levels in blood and reinitiating treatment [77].

Recently, Russo et al. reported that the profile of the LMNA-NTRK1 rearrangement in ctDNAs paralleled tumor response and resistance to entrectinib (RXDX-101, previously known as NMS-E628), a potent pan tropomyosin-related kinase (TRK), ALK, and ROS1 inhibitor [124]. It was demonstrated that molecular analysis of ctDNAs in CRC patients could provide new information of mutation status during the course of treatment and reveal resistance mechanisms $[20,25,45,54,71-74]$. These studies suggested the usefulness of application of ctDNAs for guiding treatment decision in CRC $[20,34,54,71,74,77,125]$.

\section{Conclusions and Future Perspectives}

In oncology, ctDNAs are promising biomarkers to guide clinical decision-making. Several clinical studies have been designed to further explore the utility and feasibility of this approach. Currently, there is an unmet need for predictive biomarkers of response to immune check point inhibitors such as the programmed death ligand 1 (PD-L1) inhibitors, programmed death 1 (PD1) inhibitors, and CTLA-4 antibody. High alterations in cfDNAs were related to the favorable outcomes with checkpoint inhibitor-based immunotherapy across various histologies [126]. For instance, tumor mutational burden (TMB) from cfDNAs was reported as a predictive biomarker for PFS in patients receiving atezolizumab (an anti PD-L1) in NSCLC [127]. ctDNA testing is used to accurately and reproducibly measure TMB, suggesting that ctDNAs can be a predictive biomarker in deciding the adaptation of immunotherapy. Although we focus on the use of ctDNAs in cancers with advanced stages in this review, the utility and feasibility of ctDNAs have been demonstrated in cancers at early stages as well. Further applications of ctDNAs in clinical practice require optimization, standardization, and validation of measuring ctDNAs for each purpose. Broadening our knowledge of ctDNAs, including prior knowledge of actual kinetics, will offer opportunities for non-invasive cancer management that opens new avenues for clinical practice in the near future.

Author Contributions: Performed the literature search and drafted the manuscript, A.H.-M.; participated in the critical revision and approval of the manuscript, A.S.C., T.O., S.T., and A.S.

Funding: Project for Cancer Research and Therapeutic Evolution (P-CREATE; grant number: 19cm0106402h0004).

Conflicts of Interest: The authors declare no conflict of interest. 


\section{References}

1. Coote, J.H.; Joyner, M.J. Is precision medicine the route to a healthy world? Lancet 2015, 385, 1617. [CrossRef]

2. Collins, F.S.; Varmus, H. A new initiative on precision medicine. N. Engl. J. Med. 2015, 372, $793-795$. [CrossRef] [PubMed]

3. Jameson, J.L.; Longo, D.L. Precision medicine-personalized, problematic, and promising. N. Engl. J. Med. 2015, 372, 2229-2234. [CrossRef] [PubMed]

4. Gil, E.M.C. Targeting the PI3K/AKT/mTOR pathway in estrogen receptor-positive breast cancer. Cancer Treat. Rev. 2014, 40, 862-871. [CrossRef]

5. Chan, B.A.; Hughes, B.G. Targeted therapy for non-small cell lung cancer: Current standards and the promise of the future. Transl. Lung Cancer Res. 2015, 4, 36-54. [CrossRef] [PubMed]

6. Van Cutsem, E.; Cervantes, A.; Adam, R.; Sobrero, A.; Van Krieken, J.H.; Aderka, D.; Aranda Aguilar, E.; Bardelli, A.; Benson, A.; Bodoky, G.; et al. ESMO consensus guidelines for the management of patients with metastatic colorectal cancer. Ann. Oncol. 2016, 27, 1386-1422. [CrossRef] [PubMed]

7. Van Cutsem, E.; Köhne, C.H.; Láng, I.; Folprecht, G.; Nowacki, M.P.; Cascinu, S.; Shchepotin, I.; Maurel, J.; Cunningham, D.; Tejpar, S.; et al. Cetuximab plus irinotecan, fluorouracil, and leucovorin as first-line treatment for metastatic colorectal cancer: Update analysis of overall survival according to tumor KRAS and BRAF mutation status. J. Clin. Oncol. 2011, 29, 2011-2019. [CrossRef] [PubMed]

8. Stintzing, S.; Stremitzer, S.; Sebio, A.; Lenz, H.J. Predictive and prognostic markers in the treatment of metastatic colorectal cancer (mCRC): Personalized medicine at work. Hematol. Oncol. Clin. N. Am. 2015, 29, 43-60. [CrossRef] [PubMed]

9. Allegra, C.J.; Jessup, J.M.; Somerfield, M.R.; Hamilton, S.R.; Hammond, E.H.; Hayes, D.F.; McAllister, P.K.; Morton, R.F.; Schilsky, R.L. American Society of Clinical Oncology provisional clinical opinion: Testing for KRAS gene mutations in patients with metastatic colorectal carcinoma to predict response to anti-epidermal growth factor receptor monoclonal antibody therapy. J. Clin. Oncol. 2009, 27, 2091-2096. [CrossRef]

10. Bang, Y.J.; Van Cutsem, E.; Feyereislova, A.; Chung, H.C.; Shen, L.; Sawaki, A.; Lordick, F.; Ohtsu, A.; Omuro, Y.; Satoh, T.; et al. Trastuzumab in combination with chemotherapy versus chemotherapy alone for treatment of HER2-positive advanced gastric or gastro-oesophageal junction cancer (ToGA): A phase 3, open-label, randomised controlled trial. Lancet 2010, 376, 687-697. [CrossRef]

11. Gomez-Martín, C.; Lopez-Rios, F.; Aparicio, J.; Barriuso, J.; García-Carbonero, R.; Pazo, R.; Rivera, F.; Salgado, M.; Salud, A.; Vázquez-Sequeiros, E.; et al. A critical review of HER2-positive gastric cancer evaluation and treatment: From trastuzumab, and beyond. Cancer Lett. 2014, 351, 30-40. [CrossRef] [PubMed]

12. Frenel, J.S.; Carreira, S.; Goodall, J.; Roda, D.; Perez-Lopez, R.; Tunariu, N.; Riisnaes, R.; Miranda, S.; Figueiredo, I.; Nava-Rodrigues, D.; et al. Serial Next-Generation S equencing of Circulating Cell-Free DNA Evaluating Tumor Clone Response To Molecularly Targeted Drug Administration. Clin. Cancer Res. 2015, 21, 4586-4596. [CrossRef] [PubMed]

13. Slamon, D.J.; Leyland-Jones, B.; Shak, S.; Fuchs, H.; Paton, V.; Bajamonde, A.; Fleming, T.; Eiermann, W.; Wolter, J.; Pegram, M.; et al. Use of chemotherapy plus a monoclonal antibody against HER2 for metastatic breast cancer that overexpresses HER2. N. Engl. J. Med. 2001, 344, 783-792. [CrossRef]

14. Hainsworth, J.D.; Meric-Bernstam, F.; Swanton, C.; Hurwitz, H.; Spigel, D.R.; Sweeney, C.; Burris, H.; Bose, R.; Yoo, B.; Stein, A.; et al. Targeted Therapy for Advanced Solid Tumors on the Basis of Molecular Profiles: Results from MyPathway, an Open-Label, Phase Ila Multiple Basket Study. J. Clin. Oncol. 2018, 36, 536-542. [CrossRef] [PubMed]

15. Haber, D.A.; Velculescu, V.E. Blood-based analysis of cancer: Circulating tumor cells and circulating tumor DNA. Cancer Discov. 2014, 4, 650-661. [CrossRef] [PubMed]

16. Crowley, E.; Di Nicolantonio, F.; Loupakis, F.; Bardelli, A. Liquid biopsies: Monitoring cancer-genetics in the blood. Nat. Rev. Clin. Oncol. 2013, 10, 472-484. [CrossRef]

17. Diaz, L.A., Jr.; Bardelli, A. Liquid biopsies: Genotyping circulating tumor DNA. J. Clin. Oncol. 2014, 32, 579-586. [CrossRef]

18. Matsuzaki, J.; Ochiya, T. Circulating microRNAs and extracellular vesicles as potential cancer biomarkers: A systematic review. Int. J. Clin. Oncol. 2017, 22, 413-420. [CrossRef] 
19. Wan, J.C.M.; Massie, C.; Garcia-Corbacho, J.; Mouliere, F.; Brenton, J.D.; Caldas, C.; Pacey, S.; Baird, R.; Rosenfeld, N. Liquid biopsies come of age: Towards implementation of circulating tumor DNA. Nat. Rev. Cancer 2017, 17, 223-238. [CrossRef]

20. Normanno, N.; Cervantes, A.; Ciardiello, F.; De Luca, A.; Pinto, C. The liquid biopsy in the management of colorectal cancer patients: Current applications and future scenarios. Cancer Treat. Rev. 2018, 70, 1-8. [CrossRef]

21. Otandault, A.; Anker, P.; Al Amir Dache, Z.; Guillaumon, V.; Meddeb, R.; Pastor, B.; Pisareva, E.; Sanchez, C.; Tanos, R.; Tousch, G.; et al. Recent advances in Circulating Nuclei-Acids in oncology. Ann. Oncol. 2019, 30, 374-384. [CrossRef]

22. Buono, G.; Gerratana, L.; Bulfoni, M.; Provinciali, N.; Basile, D.; Giuliano, M.; Corvaja, C.; Arpino, G.; Del Mastro, L.; De Placido, S.; et al. Circulating tumor DNA analysis in breast cancer: Is it ready for prime-time? Cancer Treat. Rev. 2019, 73, 73-83. [CrossRef]

23. Mandel, P.; Metis, P. Les acides nucléiques du plasma sanguin chez l'homme. C. R. Seances Soc. Biol. Fil. 1948, 142, 241-243. [PubMed]

24. Leon, S.A.; Shapiro, B.; Sklaroff, D.M.; Yaros, M.J. Free DNA in the serum of cancer patients and the effect of therapy. Cancer Res. 1977, 37, 646-650. [PubMed]

25. Bettegowda, C.; Sausen, M.; Leary, R.J.; Kinde, I.; Wang, Y.; Agrawal, N.; Bartlett, B.R.; Wang, H.; Luber, B.; Alani, R.M.; et al. Detection of circulating tumor DNA in early- and late-stage human malignancies. Sci. Transl. Med. 2014, 6, 224ra24. [CrossRef] [PubMed]

26. Dawson, S.J.; Tsui, D.W.; Murtaza, M.; Biggs, H.; Rueda, O.M.; Chin, S.F.; Dunning, M.J.; Gale, D.; Forshew, T.; Mahler-Araujo, B.; et al. Analysis of circulating tumor DNA to monitor metastatic breast cancer. N. Engl. J. Med. 2013, 368, 1199-1209. [CrossRef]

27. Diehl, F.; Schmidt, K.; Choti, M.A.; Romans, K.; Goodman, S.; Li, M.; Thornton, K.; Agrawal, N.; Sokoll, L.; Szabo, S.A.; et al. Circulating mutant DNA to assess tumor dynamics. Nat. Med. 2008, 14, 985-999. [CrossRef] [PubMed]

28. Madhavan, D.; Wallwiener, M.; Bents, K.; Zucknick, M.; Nees, J.; Schott, S.; Cuk, K.; Riethdorf, S.; Trumpp, A.; Pantel, K.; et al. Plasma DNA integrity as a biomarker for primary and metastatic breast cancer and potential marker for early diagnosis. Breast Cancer Res. Treat. 2014, 146, 163-174. [CrossRef] [PubMed]

29. Frackler, M.J.; Lopez Bujanda, Z.; Umbricht, C.; Teo, W.W.; Cho, S.; Zhang, Z.; Visvanathan, K.; Jeter, S.; Argani, P.; Wang, C.; et al. Novel methylated biomarkers and a robust assay to detect circulating tumor DNA in metastatic breast cancer. Cancer Res. 2014, 74, 2160-2170. [CrossRef]

30. Rothé, F.; Laes, J.F.; Lambrechts, D.; Smeets, D.; Vincent, D.; Maetens, M.; Fumagalli, D.; Michiels, S.; Drisis, S.; Moerman, C.; et al. Plasma circulating tumor DNA as an alternative to metastatic biopsies for mutational analysis in breast cancer. Ann. Oncol. 2014, 25, 1959-1965. [CrossRef] [PubMed]

31. Murtaza, M.; Dawson, S.J.; Pogrebniak, K.; Rueda, O.M.; Provenzano, E.; Grant, J.; Chin, S.F.; Tsui, D.W.Y.; Marass, F.; Gale, D.; et al. Multifocal clonal evolution characterized using circulating tumour DNA in a case of metastatic breast cancer. Nat. Commun. 2015, 6, 8760. [CrossRef] [PubMed]

32. Kuo, Y.B.; Chen, J.S.; Fan, C.W.; Li, Y.S.; Chan, E.C. Comparison of KRAS mutation analysis of primary tumors and matched circulating cell-free DNA in plasma of patients with colorectal cancer. Clin. Chim. Acta 2014, 433, 284-289. [CrossRef] [PubMed]

33. Thierry, A.R.; Mouliere, F.; El Messaoudi, S.; Mollevi, C.; Lopez-Crapez, E.; Rolet, F.; Gillet, B.; Gongora, C.; Dechelotte, P.; Robert, B.; et al. Clinical validation of the detection of KRAS and BRAF mutations from circulating tumor DNA. Nat. Med. 2014, 20, 430-435. [CrossRef] [PubMed]

34. Spindler, K.L.; Pallisgaard, N.; Appelt, A.L.; Andersen, R.F.; Schou, J.V.; Nielsen, D.; Pfeiffer, P.; Yilmaz, M.; Johansen, J.S.; Hoegdall, E.V.; et al. Clinical utility of KRAS status in circulating plasma DNA compared to archival tumour tissue from patients with metastatic colorectal cancer treated with anti-epidermal growth factor receptor therapy. Eur. J. Cancer 2015, 51, 2678-2685. [CrossRef] [PubMed]

35. Perrone, F.; Lampis, A.; Bertan, C.; Verderio, P.; Ciniselli, C.M.; Pizzamiglio, S.; Frattini, M.; Nucifora, M.; Molinari, F.; Gallino, G.; et al. Circulating free DNA in a screening program for early colorectal cancer detection. Tumori 2014, 100, 115-121. [CrossRef] [PubMed]

36. Zhou, Y.; Wang, C.; Zhu, H.; Lin, Y.; Pan, B.; Zhang, X.; Huang, X.; Xu, Q.; Xu, Y.; Sun, Q. Diagnostic Accuracy of PIK3CA Mutation Detection by Circulating Free DNA in Breast Cancer: A Meta-Analysis of Diagnostic Test Accuracy. PLoS ONE 2016, 11, e0158143. [CrossRef] [PubMed] 
37. Aucamp, J.; Bronkhorst, A.J.; Badenhorst, C.P.S.; Pretorius, P.J. The diverse origins of circulating cell-free DNA in the human body: A critical re-evaluation of the literature. Biol. Rev. Camb. Philos. Soc. 2018, 93, 1649-1683. [CrossRef] [PubMed]

38. Tan, D.S.; Yom, S.S.; Tsao, M.S.; Pass, H.I.; Kelly, K.; Peled, N.; Yung, R.C.; Wistuba, I.I.; Yatabe, Y.; Unger, M.; et al. The international Association for the Study of Lung Cancer Consensus Statement on Optimizing Management of EGFR Mutation-Positive Non-Small Cell Lung Cancer: Status in 2016. J. Thorac. Oncol. 2016, 11, 946-963. [CrossRef] [PubMed]

39. Mok, T.; Wu, Y.L.; Lee, J.S.; Yu, C.J.; Sriuranpong, V.; Sandoval-Tan, J.; Ladrera, G.; Thongprasert, S.; Srimuninnimit, V.; Liao, M.; et al. Detection and Dynamic Changes of EGFR Mutations from Circulating Tumor DNA as a Predictor of Survival Outcomes in NSCLC Patients Treated with First-line Intercalated Erlotinib and Chemotherapy. Clin. Cancer Res. 2015, 21, 3196-3203. [CrossRef]

40. Douillard, J.Y.; Ostoros, G.; Cobo, M.; Ciuleanu, T.; Cole, R.; McWalter, G.; Walker, J.; Dearden, S.; Webster, A.; Milenkova, T.; et al. Gefitinib treatment in EGFR mutated caucasian NSCLC: Circulating-free tumor DNA as a surrogate for determination of EGFR status. J. Thorac. Oncol. 2014, 9, 1345-1353. [CrossRef]

41. Newman, A.M.; Bratman, S.V.; To, J.; Wynne, J.F.; Eclov, N.C.; Modlin, L.A.; Liu, C.L.; Neal, J.W.; Wakelee, H.A.; Merritt, R.E.; et al. An ultrasensitive method for quantitating circulating tumor DNA with broad patient coverage. Nat. Med. 2014, 20, 548-554. [CrossRef] [PubMed]

42. Hindson, B.J.; Ness, K.D.; Masquelier, D.A.; Belgrader, P.; Heredia, N.J.; Makarewicz, A.J.; Bright, I.J.; Lucero, M.Y.; Hiddessen, A.L.; Legler, T.C.; et al. High-throughput droplet digital PCR system for absolute quantitation of DNA copy number. Anal. Chem. 2011, 83, 8604-8610. [CrossRef] [PubMed]

43. Sausen, M.; Parpart, S.; Diaz, L.A., Jr. Circulating tumor DNA moves further into the spotlight. Genome Med. 2014, 6, 35. [CrossRef] [PubMed]

44. Esposito, A.; Bardelli, A.; Criscitiello, C.; Colombo, N.; Gelao, L.; Fumagalli, L.; Minchella, I.; Locatelli, M.; Goldhirsch, A.; Curigliano, G. Monitoring tumor-derived cell-free DNA in patients with solid tumors: Clinical perspective and research opportunities. Cancer Treat. Rev. 2014, 40, 648-655. [CrossRef] [PubMed]

45. Vidal, J.; Muinelo, L.; Dalmases, A.; Jones, F.; Edelstein, D.; Iglesias, M.; Orrillo, M.; Abalo, A.; Rodríguez, C.; Brozos, E.; et al. Plasma ctDNA RAS mutation analysis for the diagnosis and treatment monitoring of metastatic colorectal cancer patients. Ann. Oncol. 2017, 28, 1325-1332. [CrossRef] [PubMed]

46. Lin, J.J.; Cardarella, S.; Lydon, C.A.; Dahlberg, S.E.; Jackman, D.M.; Jänne, P.A.; Johnson, B.E. Five-Year Survival in EGFR-Mutant Metastatic Lung Adenocarcinoma Treated with EGFR-TKIs. J. Thorac. Oncol. 2016, 11, 556-565. [CrossRef]

47. Mok, T.S.; Wu, Y.-L.; Ahn, M.-J.; Garassino, M.C.; Kim, H.R.; Ramalingam, S.S.; Shepherd, F.A.; He, Y.; Akamatsu, H.; Theelen, W.S.; et al. Osimertinib or Platinum-Pemetrexed in EGFR T790M-Positive Lung Cancer. N. Engl. J. Med. 2017, 376, 629-640. [CrossRef]

48. Zill, O.A.; Banks, K.C.; Fairclough, S.R.; Mortimer, S.A.; Vowles, J.V.; Mokhtari, R.; Gandara, D.R.; Mack, P.C.; Odegaard, J.I.; Nagy, R.J.; et al. The Landscape of Actionable Genomic Alterations in Cell-Free Circulating Tumor DNA from 21,807 Advanced Cancer Patients. Clin. Cancer Res. 2018, 24, 3528-3538. [CrossRef]

49. Qiu, M.; Wang, J.; Xu, Y.; Ding, X.; Li, M.; Jiang, F.; Xu, L.; Yin, R. Circulating tumor DNA is effective for the detection of EGFR mutation in non-small cell lung cancer: A meta-analysis. Cancer Epidemiol. Biomark. Prev. 2015, 24, 206-212. [CrossRef]

50. Xie, W.; Xie, L.; Song, X. The diagnostic accuracy of circulating free DNA for the detection of KRAS mutation status in colorectal cancer: A meta-analysis. Cancer Med. 2019, 8, 1218-1231. [CrossRef]

51. Russo, M.; Siravegna, G.; Blaszkowsky, L.S.; Corti, G.; Crisafulli, G.; Ahronian, L.G.; Mussolin, B.; Kwak, E.L.; Buscarino, M.; Lazzari, L.; et al. Tumor Heterogeneity and Lesion-Specific Response to Targeted Therapy in Colorectal Cancer. Cancer Discov. 2016, 6, 147-153. [CrossRef]

52. Goldman, J.W.; Noor, Z.S.; Remon, J.; Besse, B.; Rosenfeld, N. Are liquid biopsies a surrogate for tissue EGFR testing? Ann. Oncol. 2018, 29 (Suppl. 1), i38-i46. [CrossRef] [PubMed]

53. Sacher, A.G.; Paweletz, C.; Dahlberg, S.E.; Alden, R.S.; O'Connell, A.; Feeney, N.; Mach, S.L.; Jänne, P.A.; Oxnard, G.R. Prospective Validation of Rapid Plasma Genotyping for the Detection of EGFR and KRAS Mutations in Advanced Lung Cancer. JAMA Oncol. 2016, 2, 1014-1022. [CrossRef] [PubMed]

54. Diaz, L.A., Jr.; Williams, R.T.; Wu, J.; Kinde, I.; Hecht, J.R.; Berlin, J.; Allen, B.; Bozic, I.; Reiter, J.G.; Nowak, M.A.; et al. The molecular evolution of acquired resistance to targeted EGFR blockade in colorectal cancers. Nature 2012, 486, 537-540. [CrossRef] [PubMed] 
55. Bordi, P.; Del Re, M.; Danesi, R.; Tiseo, M. Circulating DNA in diagnosis and monitoring EGFR gene mutations in advanced non-small cell lung cancer. Transl. Lung Cancer Res. 2015, 4, 584-597. [CrossRef] [PubMed]

56. Garcia-Murillas, I.; Schiavon, G.; Weigelt, B.; Ng, C.; Hrebien, S.; Cutts, R.J.; Cheang, M.; Osin, P.; Nerurkar, A.; Kozarewa, I.; et al. Mutation tracking in circulating tumor DNA predicts relapse in early breast cancer. Sci. Transl. Med. 2015, 7, 302ra133. [CrossRef] [PubMed]

57. Stötzer, O.J.; Lehner, J.; Fersching-Gierlich, D.; Nagel, D.; Holdenrieder, S. Diagnostic relevance of plasma DNA and DNA integrity for breast cancer. Tumor Biol. 2014, 35, 1183-1191. [CrossRef]

58. Oxnard, G.R.; Paweletz, C.P.; Kuang, Y.; Mach, S.L.; O'Connell, A.; Messineo, M.M.; Luke, J.J.; Butaney, M.; Kirschmeier, P.; Jackman, D.M.; et al. Noninvasive detection of response and resistance in EGFR-mutant lung cancer using quantitative next-generation genotyping of cell-free plasma DNA. Clin. Cancer Res. 2014, 20, 1698-1705. [CrossRef]

59. Sorensen, B.S.; Wu, L.; Wei, W.; Tsai, J.; Weber, B.; Nexo, E.; Meldgaard, P. Monitoring of epidermal growth factor receptor tyrosine kinase inhibitor-sensitizing and resistance mutations in the plasma DNA of patients with advanced non-small cell lung cancer during treatment with erlotinib. Cancer 2014, 120, 3896-3901. [CrossRef]

60. Lee, J.Y.; Qing, X.; Xiumin, W.; Yali, B.; Chi, S.; Bak, S.H.; Lee, H.Y.; Sun, J.M.; Lee, S.H.; Ahn, J.S.; et al. Longitudinal monitoring of EGFR mutations in plasma predicts outcomes of NSCLC patients treated with EGFR TKIs: Korean Lung Cancer Consortium (KLCC-12-02). Oncotarget 2016, 7, 6984-6993. [CrossRef]

61. Ma, F.; Zhu, W.; Guan, Y.; Yang, L.; Xia, X.; Chen, S.; Li, Q.; Guan, X.; Yi, Z.; Qian, H.; et al. ctDNA dynamics: A novel indicator to track resistance in metastatic breast cancer treated with anti-HER2 therapy. Oncotarget 2016, 7, 66020-66031. [CrossRef] [PubMed]

62. Thress, K.S.; Paweletz, C.P.; Felip, E.; Cho, B.C.; Stetson, D.; Dougherty, B.; Lai, Z.; Markovets, A.; Vivancos, A.; Kuang, Y.; et al. Acquired EGFR C797S mutation mediates resistance to AZD9291 in non-small cell lung cancer harbouring EGFR T790M. Nat. Med. 2015, 21, 560-562. [CrossRef] [PubMed]

63. Piotrowska, Z.; Niederst, M.J.; Karlovich, C.A.; Wakelee, H.A.; Neal, J.W.; Mino-Kenudson, M.; Fulton, L.; Hata, A.N.; Lockerman, E.L.; Kalsy, A.; et al. Heterogeneity Underlies the Emergence of EGFR T790 Wild-Type Clones Following Treatment of T790M-positive Cancers with a Third-Generation EGFR Inhibitor. Cancer Discov. 2015, 5, 713-722. [CrossRef] [PubMed]

64. Wang, Z.; Chen, R.; Wang, S.; Zhong, J.; Wu, M.; Zhao, J.; Duan, J.; Zhuo, M.; An, T.; Wang, Y.; et al. Quantification and dynamic monitoring of EGFR T790M in plasma cell-free DNA by digital PCR for prognosis of EGFR-TKI treatment in advanced NSCLC. PLOS ONE 2014, 9, e110780. [CrossRef]

65. Tseng, J.S.; Yang, T.Y.; Tsai, C.R.; Chen, K.C.; Hsu, K.H.; Tsai, M.H.; Yu, S.L.; Su, K.Y.; Chen, J.J.; Chang, G.C. Dynamic plasma EGFR mutation status as a predictor of EGFR-TKI efficacy in patients with EGFR-mutant lung adenocarcinoma. J. Thorac. Oncol. 2015, 10, 603-610. [CrossRef]

66. Zheng, D.; Ye, X.; Zhang, M.Z.; Sun, Y.; Wang, J.Y.; Ni, J.; Zhang, H.P.; Zhang, L.; Luo, J.; Zhang, J.; et al. Plasma EGFR T790M ctDNA status is associated with clinical outcome in advanced NSCLC patients with acquired EGFR-TKI resistance. Sci. Rep. 2016, 6, 20913. [CrossRef] [PubMed]

67. Remon, J.; Steuer, C.E.; Ramalingam, S.S.; Felip, E. Osimertinib and other third-generation EGFR TKI in EGFR-mutant NSCLC patients. Ann. Oncol. 2018, 29 (Suppl. 1), i20-i27. [CrossRef]

68. Blakely, C.M.; Watkins, T.B.K.; Wu, W.; Gini, B.; Chabon, J.J.; McCoach, C.E.; McGranahan, N.; Wilson, G.A.; Birkbak, N.J.; Olivas, V.R.; et al. Evolution and clinical impact of co-occurring genetic alterations in advanced-stage EGFR-mutant lung cancers. Nat. Genet. 2017, 49, 1693-1704. [CrossRef]

69. Siravegna, G.; Mussolin, B.; Buscarino, M.; Corti, G.; Cassingena, A.; Crisafulli, G.; Ponzetti, A.; Cremolini, C.; Amatu, A.; Lauricella, C.; et al. Clonal evolution and resistance to EGFR blockade in the blood of colorectal cancer patients. Nat. Med. 2015, 21, 827. [CrossRef]

70. Chabon, J.J.; Simmons, A.D.; Lovejoy, A.F.; Esfahani, M.S.; Newman, A.M.; Haringsma, H.J.; Kurtz, D.M.; Stehr, H.; Scherer, F.; Karlovich, C.A.; et al. Circulating tumour DNA profiling reveals heterogeneity of EGFR inhibitors resistance mechanisms in lung cancer patients. Nat. Commun. 2016, 7, 11815. [CrossRef]

71. Misale, S.; Yaeger, R.; Hobor, S.; Scala, E.; Janakiraman, M.; Liska, D.; Valtorta, E.; Schiavo, R.; Buscarino, M.; Siravegna, G.; et al. Emergence of KRAS mutations and acquired resistance to anti-EGFR therapy in colorectal cancer. Nature 2012, 486, 532-536. [CrossRef] [PubMed] 
72. Van Emburgh, B.O.; Arena, S.; Siravegna, G.; Lazzari, L.; Crisafulli, G.; Corti, G.; Mussolin, B.; Baldi, F.; Buscarino, M.; Bartolini, A.; et al. Acquired RAS or EGFR mutations and duration of response to EGFR blockade in colorectal cancer. Nat. Commun. 2016, 7, 13665. [CrossRef] [PubMed]

73. Morelli, M.P.; Overman, M.J.; Dasari, A.; Kazmi, S.M.; Mazard, T.; Vilar, E.; Morris, V.K.; Lee, M.S.; Herron, D.; Eng, C.; et al. Characterizing the patterns of clonal selection in circulating tumor DNA from patients with colorectal cancer refractory to anti-EGFR treatment. Ann. Oncol. 2015, 26, 731-736. [CrossRef] [PubMed]

74. Spindler, K.L.; Pallisgaard, N.; Andersen, R.F.; Jakobsen, A. Changes in mutational status during third-line treatment for metastatic colorectal cancer: Results of consecutive measurement of cell free DNA, KRAS and BFAF in the plasma. Int. J. Cancer 2014, 135, 2215-2222. [CrossRef] [PubMed]

75. Bardelli, A.; Corso, S.; Bertotti, A.; Hobor, S.; Valtorta, E.; Siravegna, G.; Sartore-Bianchi, A.; Scala, E.; Cassingena, A.; Zecchin, D.; et al. Amplification of the MET receptor drives resistance to anti-EGFR therapies in colorectal cancer. Cancer Discov. 2013, 3, 658-673. [CrossRef] [PubMed]

76. Imamura, F.; Uchida, J.; Kukita, Y.; Kumagai, T.; Nishino, K.; Inoue, T.; Kimura, M.; Oba, S.; Kato, K. Monitoring of treatment responses and clonal evolution of tumor cells by circulating tumor DNA of heterogeneous mutant EGFR genes in lung cancer. Lung Cancer 2016, 94, 68-73. [CrossRef] [PubMed]

77. Parseghian, C.M.; Loree, J.M.; Morris, V.K.; Liu, X.; Clifton, K.K.; Napolitano, S.; Henry, J.T.; Pereira, A.A.; Vilar, E.; Johnson, B.; et al. Anti-EGFR-resistant clones decay exponentially after progression: Implications for anti-EGFR re-challenge. Ann. Oncol. 2019, 30, 243-249. [CrossRef] [PubMed]

78. Xiong, L.; Cui, S.; Ding, J.; Sun, Y.; Zhang, L.; Zhao, Y.; Gu, A.; Chu, T.; Wang, H.; Zhong, H.; et al. Dynamics of EGFR mutations in plasma recapitulates the clinical response to EGFR-TKIs in NSCLC patients. Oncotarget 2017, 8, 63846-63856. [CrossRef]

79. Midha, A.; Dearden, S.; McCormack, R. EGFR mutation incidence in non-small-cell lung cancer of adenocarcinoma histology: A systematic review and global map by ethnicity (mutMapII). Am. J. Cancer Res. 2015, 5, 2892-2911.

80. Yu, H.A.; Arcila, M.E.; Rekhtman, N.; Sima, C.S.; Zakowski, M.F.; Pao, W.; Kris, M.G.; Miller, V.A.; Ladanyi, M.; Riely, G.J. Analysis of tumor specimens at the time of acquired resistance to EGFR-TKI therapy in 155 patients with EGFR-mutant lung cancers. Clin. Cancer Res. 2013, 19, 2240-2247. [CrossRef]

81. Kobayashi, Y.; Mitsudomi, T. Not all epidermal growth factor receptor mutations in lung cancer are created equal: Perspective for individualized treatment strategy. Cancer Sci. 2016, 107, 1179-1186. [CrossRef] [PubMed]

82. Reck, M.; Hagiwara, K.; Han, B.; Tjulandin, S.; Grohé, C.; Yokoi, T.; Morabito, A.; Novello, S.; Arriola, E.; Molinier, O.; et al. ctDNA Determination of EGFR Mutation Status in European and Japanese Patients with Advanced NSCLC: The ASSESS Study. J. Thorac. Oncol. 2016, 11, 1682-1689. [CrossRef] [PubMed]

83. Qian, X.; Liu, J.; Sun, Y.; Wang, M.; Lei, H.; Luo, G.; Liu, X.; Xiong, C.; Liu, D.; Liu, J.; et al. Circulating cell-free DNA has a high degree of specificity to detect exon 19 deletions and the single-point substitution mutation L858R in non-small cell lung cancer. Oncotarget 2016, 7, 29154-29165. [CrossRef] [PubMed]

84. Li, X.; Ren, R.; Ren, S.; Chen, X.; Cai, W.; Zhou, F.; Zhang, Y.; Su, C.; Zhao, C.; Li, J.; et al. Peripheral blood for epidermal growth factor receptor mutation detection in non-small cell lung cancer patients. Trans. Oncol. 2014, 7, 341-348. [CrossRef] [PubMed]

85. Weber, B.; Meldgaard, P.; Hager, H.; Wu, L.; Wei, W.; Tsai, J.; Khalil, A.; Nexo, E.; Sorensen, B.S. Detection of EGFR mutations in plasma and biopsies from non-small cell lung cancer patients by allele-specific PCR assays. BMC Cancer 2014, 14, 294. [CrossRef] [PubMed]

86. Marchetti, A.; Palma, J.F.; Felicioni, L.; De Pas, T.M.; Chiari, R.; Del Grammastro, M.; Filice, G.; Ludovini, V.; Brandes, A.A.; Chella, A.; et al. Early Prediction of Response to Tyrosine Kinase Inhibitors by Quantification of EGFR Mutations in Plasma of NSCLC Patients. J. Thorac. Oncol. 2015, 10, 1437-1443. [CrossRef]

87. Li, X.; Zhou, C. Comparison of cross-platform technologies for EGFR T790M testing in patients with non-small cell lung cancer. Oncotarget 2017, 8, 100801-100818. [CrossRef] [PubMed]

88. Sundaresan, T.K.; Sequist, L.V.; Heymach, J.V.; Riely, G.J.; Jänne, P.A.; Koch, W.H.; Sullivan, J.P.; Fox, D.B.; Maher, R.; Muzikansky, A.; et al. Detection of T790M, the Acquired Resistance EGFR Mutation, by Tumor Biopsy versus Noninvasive Blood-Based Analyses. Clin. Cancer Res. 2016, 22, 1103-1110. [CrossRef]

89. Jänne, P.A.; Yang, J.C.; Kim, D.W.; Planchard, D.; Ohe, Y.; Ramalingam, S.S.; Ahn, M.J.; Kim, S.W.; Su, W.C.; Horn, L.; et al. AZD9291 in EGFR inhibitor-resistant non-small-cell lung cancer. N. Engl. J. Med. 2015, 372, 1689-1699. [CrossRef] 
90. Tan, C.S.; Cho, B.C.; Soo, R.A. Next-generation epidermal growth factor receptor tyrosine kinase inhibitors in epidermal growth factor receptor-mutant non-small cell lung cancer. Lung Cancer 2016, 93, 59-68. [CrossRef]

91. Sequist, L.V.; Soria, J.C.; Goldman, J.W.; Wakelee, H.A.; Gadgeel, S.M.; Varga, A.; Papadimitrakopoulou, V.; Solomon, B.J.; Oxnard, G.R.; Dziadziuszko, R.; et al. Rociletinib in EGFR-mutated non-small-cell lung cancer. N. Engl. J. Med. 2015, 372, 1700-1709. [CrossRef] [PubMed]

92. Helman, E.; Nguyen, M.; Karlovich, C.A.; Despain, D.; Choquette, A.K.; Spira, A.I.; Yu, H.A.; Camidge, D.R.; Harding, T.C.; Lanman, R.B.; et al. Cell-Free DNA Next-Generation Sequencing Prediction of Response and Resistance to Third-Generation EGFR Inhibitor. Clin. Lung Cancer 2018, 19, 518-530.e7. [CrossRef] [PubMed]

93. Sørlie, T.; Perou, C.M.; Tibshirani, R.; Aas, T.; Geisler, S.; Johnsen, H.; Hastie, T.; Eisen, M.B.; van de Rijn, M.; Jeffrey, S.S.; et al. Gene expression patterns of breast carcinoma distinguish tumor subclasses with clinical implications. Proc. Natl. Acad. Sci. USA 2001, 98, 10869-10874. [CrossRef] [PubMed]

94. Curigliano, G.; Burstein, H.J.; Winer, E.P.; Gnant, M.; Dubsky, P.; Loibl, S.; Colleoni, M.; Regan, M.M.; Piccart-Gebhart, M.; Senn, H.J.; et al. De-escalating and escalating treatments for early-stage breast cancer: The St. Gallen International Expert Consensus Conference on the Primary Therapy of Early Breast Cancer 2017. Ann. Oncol. 2019. [CrossRef]

95. Wei, W.; Zhang, X.; Sun, S.; Xia, B.; Liang, X.; Cui, Y.; Gao, S.; Pang, D. Assessment of basal-like breast cancer by circulating tumor DNA analysis. Oncol. Lett. 2018, 15, 7389-7396. [CrossRef] [PubMed]

96. Pritchard, K.I. Endocirne therapy: Is the first generation of targeted drugs the last? J. Intern. Med. 2013, 274, 144-152. [CrossRef]

97. Rugo, H.S.; Li, H.; Gui, X. Strategies and Progress of Endocrine Therapy for Patients with Metastatic Breast Cancer. Adv. Exp. Biol. 2017, 1026, 403-418. [CrossRef]

98. Angus, L.; Beije, N.; Jager, A.; Martens, J.W.; Sleijfer, S. ESR1 mutations: Moving towards guiding treatment decision-making in metastatic breast cancer patients. Cancer Treat. Rev. 2017, 52, 33-40. [CrossRef]

99. Chu, D.; Paoletti, C.; Gersch, C.; VanDenBerg, D.A.; Zabransky, D.J.; Cochran, R.L.; Wong, H.Y.; Toro, P.V.; Cidado, J.; Croessmann, S.; et al. ESR1 Mutations in Circulating Plasma Tumor DNA from Metastatic Breast Cancer Patients. Clin. Cancer Res. 2016, 22, 993-999. [CrossRef]

100. Takeshita, T.; Yamamoto, Y.; Yamamoto-Ibusuki, M.; Inao, T.; Sueta, A.; Fujiwara, S.; Omoto, Y.; Iwase, H. Droplet digital polymerase chain reaction assay for screening of ESR1 mutations in 325 breast cancer specimens. Trans. Res. 2015, 166, 540-553.e2. [CrossRef]

101. Wang, P.; Bahreini, A.; Gyanchandani, R.; Lucas, P.C.; Hartmaier, R.J.; Watters, R.J.; Jonnalagadda, A.R.; Trejo Bittar, H.E.; Berg, A.; Hamilton, R.L.; et al. Sensitive Detection of Mono- and Polyclonal ESR1 Mutations in Primary Tumors, Metastatic Lesions, and Cell-Free DNA of Breast Cancer Patients. Clin. Cancer Res. 2016, 22, 1130-1137. [CrossRef] [PubMed]

102. Fribbens, C.; Garcia Murillas, I.; Beaney, M.; Hrebien, S.; O’Leary, B.; Kilburn, L.; Howarth, K.; Epstein, M.; Green, E.; Rosenfeld, N.; et al. Tracking evolution of aromatase inhibitor resistance with circulating tumour DNA analysis in metastatic breast cancer. Ann. Oncol. 2018, 29, 145-153. [CrossRef] [PubMed]

103. Sefrioui, D.; Perdrix, A.; Sarafan-Vasseur, N.; Dolfus, C.; Dujon, A.; Picquenot, J.M.; Delacour, J.; Cornic, M.; Bohers, E.; Leheurteur, M.; et al. Shorter report: Monitoring ESR1 mutations by circulating tumor DNA in aromatase inhibitor resistant metastatic breast cancer. Int. J. Cancer 2015, 137, 2513-2519. [CrossRef] [PubMed]

104. Guttery, D.S.; Page, K.; Hills, A.; Woodley, L.; Marchese, S.D.; Rghebi, B.; Hastings, R.K.; Luo, J.; Pringle, J.H.; Stebbing, J.; et al. Noninvasive detection of activating estrogen receptor 1 (ESR1) mutations in estrogen receptor-positive metastatic breast cancer. Clin. Chem. 2015, 61, 974-982. [CrossRef] [PubMed]

105. Mastoraki, S.; Strati, A.; Tzanikou, E.; Chimonidou, M.; Politaki, E.; Voutsina, A.; Psyrri, A.; Georgoulias, V.; Lianidou, E. ESR1 Methylation: A Liquid Biopsy-Based Epigenetic Assay for the Follow-up of Patients with Metastatic Breast Cancer Receiving Endocrine Treatment. Clin. Cancer Res. 2018, 24, 1500-1510. [CrossRef] [PubMed]

106. Schiavon, G.; Hrebien, S.; Garcia-Murillas, I.; Cutts, R.J.; Pearson, A.; Tarazona, N.; Fenwick, K.; Kozarewa, I.; Lopez-Knowles, E.; Ribas, R.; et al. Analysis of ESR1 mutation in circulating tumor DNA demonstrates evolution during therapy for metastatic breast cancer. Sci. Trans. Med. 2015, 7, 313ra182. [CrossRef] [PubMed] 
107. Chandarlapaty, S.; Chen, D.; He, W.; Sung, P.; Samoila, A.; You, D.; Bhatt, T.; Patel, P.; Voi, M.; Gnant, M.; et al. Prevalence of ESR1 mutations in Cell-Free DNA and Outcomes in Metastatic Breast Cancer: A Secondary Analysis of the BOLERO-2 Clinical Trial. JAMA Oncol. 2016, 2, 1310-1315. [CrossRef] [PubMed]

108. Allouchery, V.; Beaussire, L.; Perdrix, A.; Sefrioui, D.; Augusto, L.; Guillemet, C.; Sarafan-Vasseur, N.; Di Fiore, F.; Clatot, F. Circulating ESR1 mutations at the end of aromatase inhibitor adjuvant treatment and after relapse in breast cancer patients. Breast Cancer Res. 2018, 20, 40. [CrossRef] [PubMed]

109. O'Leary, B.; Hrebien, S.; Morden, J.P.; Beaney, M.; Fribbens, C.; Huang, X.; Liu, Y.; Bartlett, C.H.; Koehler, M.; Cristofanilli, M.; et al. Early circulating tumor DNA dynamics and clonal selection with palbociclib and fulvestrant for breast cancer. Nat. Commun. 2018, 9, 896. [CrossRef] [PubMed]

110. Cristofanilli, M.; Turner, N.C.; Bondarenko, I.; Ro, J.; Im, S.A.; Masuda, N.; Colleoni, M.; DeMichele, A.; Loi, S.; Verma, S.; et al. Fulvestrant plus palbociclib versus fulvestrant plus placebo for treatment of hormone-receptor-positive, HER2-negative metastatic breast cancer that progressed on previous endocrine therapy (PALOMA-3): Final analysis of the multicentre, double-blind, phase 3 randomised controlled trial. Lancet Oncol. 2016, 17, 425-439. [CrossRef]

111. Cancer Genome Atlas Network. Comprehensive molecular portraits of human breast tumours. Nature 2012, 490, 61-70. [CrossRef]

112. Baselga, J.; Im, S.A.; Iwata, H.; Cortés, J.; De Laurentiis, M.; Jiang, Z.; Arteaga, C.L.; Jonat, W.; Clemons, M.; Ito, Y.; et al. Buparlisib plus fulvestrant versus placebo plus fulvestrant in postmenopausal, hormone receptor-positive, HER2-negative, advanced breast cancer (BELLE-2): A randomised, double-blind, placebo-controlled, phase 3 trial. Lancet Oncol. 2017, 18, 904-916. [CrossRef]

113. Moynahan, M.E.; Chen, D.; He, W.; Sung, P.; Samoila, A.; You, D.; Bhatt, T.; Patel, P.; Ringeisen, F.; Hortobagyi, G.N.; et al. Correlation between PIK3CA mutations in cell-free DNA and everolimus efficacy in HR+, HER2- advanced breast cancer: Results from BOLERO-2. Br. J. Cancer 2017, 116, 726-730. [CrossRef] [PubMed]

114. Page, K.; Hava, N.; Ward, B.; Brown, J.; Guttery, D.S.; Ruangpratheep, C.; Blighe, K.; Sharma, A.; Walker, R.A.; Coombes, R.C.; et al. Detection of HER2 amplification in circulating free DNA in patients with breast cancer. Br. J. Cancer 2011, 104, 1342-1348. [CrossRef] [PubMed]

115. Ma, C.X.; Bose, R.; Gao, F.; Freedman, R.A.; Telli, M.L.; Kimmick, G.; Winer, E.; Naughton, M.; Goetz, M.P.; Russell, C.; et al. Neratinib Efficacy and Circulating Tumor DNA Detection of HER2 Mutations in HER2 Nonamplified Metastatic Breast Cancer. Clin. Cancer Res. 2017, 23, 5687-5695. [CrossRef] [PubMed]

116. Robson, M.; Im, S.A.; Senkus, E.; Xu, B.; Domchek, S.M.; Masuda, N.; Delaloge, S.; Li, W.; Tung, N.; Armstrong, A.; et al. Olaparib for Metastatic Breast Cancer in Patients with a Germline BRCA Mutation. N. Engl. J. Med. 2017, 377, 523-533. [CrossRef] [PubMed]

117. Dhillon, K.K.; Swisher, E.M.; Taniguchi, T. Secondary mutations of BRCA 1/2 and drug resistance. Cancer Sci. 2011, 102, 663-669. [CrossRef] [PubMed]

118. Weigelt, B.; Comino-Méndez, I.; de Bruijn, I.; Tian, L.; Meisel, J.L.; García-Murillas, I.; Fribbens, C.; Cutts, R.; Martelotto, L.G.; Ng, C.K.Y.; et al. Diverse BRCA1and BRCA2 Reversion Mutations in Circulating Cell-Free DNA of Therapy-resistant Breast or Ovarian Cancer. Clin. Cancer. Res. 2017, 23, 6708-6720. [CrossRef]

119. Liang, D.H.; Ensor, J.E.; Liu, Z.B.; Patel, A.; Patel, T.A.; Chang, J.C.; Rodriguez, A.A. Cell-free DNA as a molecular tool for monitoring disease progression and response to therapy in breast cancer patients. Breast Cancer Res. Treat. 2016, 155, 139-149. [CrossRef]

120. Tie, J.; Kinde, I.; Wang, Y.; Wong, H.L.; Roebert, J.; Christie, M.; Tacey, M.; Wong, R.; Singh, M.; Karapetis, C.S.; et al. Circulating tumor DNA as an early marker of therapeutic response in patients with metastatic colorectal cancer. Ann. Oncol. 2015, 26, 1715-1722. [CrossRef]

121. McCormick, F. K-Ras protein as a drug target. J. Mol. Med. 2016, 94, 253-258. [CrossRef] [PubMed]

122. Siravegna, G.; Sartore-Bianchi, A.; Nagy, R.J.; Raghav, K.; Odegaard, J.I.; Lanman, R.B.; Trusolino, L.; Marsoni, S.; Siena, S.; Bardelli, A. Plasma HER2 (ERBB2) Copy Number Predicts Response to HER2-targeted Therapy in Metastatic Colorectal Cancer. Clin. Cancer Res. 2019, 25, 3046-3053. [CrossRef] [PubMed]

123. Mauri, G.; Pizzutilo, E.G.; Amatu, A.; Bencardino, K.; Palmeri, L.; Bonazzina, E.F.; Tosi, F.; Carlo Stella, G.; Burrafato, G.; Scaglione, F.; et al. Retreatment with anti-EGFR monoclonal antibodies in metastatic colorectal cancer: Systematic review of different strategies. Cancer Treat. Rev. 2019, 73, 41-53. [CrossRef] [PubMed] 
124. Russo, M.; Misale, S.; Wei, G.; Siravegna, G.; Crisafulli, G.; Lazzari, L.; Corti, G.; Rospo, G.; Novara, L.; Mussolin, B.; et al. Acquired Resistance to the TRK Inhibitor Entrectinib in Colorectal Cancer. Cancer Discov. 2016, 6, 36-44. [CrossRef]

125. Spindler, K.L.; Appelt, A.L.; Pallisgaard, N.; Andersen, R.F.; Brandslund, I.; Jakobsen, A. Cell-free DNA in healthy individuals, noncancerous disease and strong prognosis value in colorectal cancer. Int. J. Cancer 2014, 135, 2984-2991. [CrossRef] [PubMed]

126. Khagi, Y.; Goodman, A.M.; Daniels, G.A.; Patel, S.P.; Sacco, A.G.; Randall, J.M.; Bazhenova, L.A.; Kurzrock, R. Hypermutated Circulating Tumor DNA: Correlation with Response to Checkpoint Inhibitor-Based Immunotherapy. Clin. Cancer Res. 2017, 23, 5729-5736. [CrossRef]

127. Gandara, D.R.; Paul, S.M.; Kowanetz, M.; Schleifman, E.; Zou, W.; Li, Y.; Rittmeyer, A.; Fehrenbacher, L.; Otto, G.; Malboeuf, C.; et al. Blood-based tumor mutational burden as a predictor of clinical benefit in non-small-cell lung cancer patients treated with atezolizumab. Nat. Med. 2018, 24, 1441-1448. [CrossRef]

(C) 2019 by the authors. Licensee MDPI, Basel, Switzerland. This article is an open access article distributed under the terms and conditions of the Creative Commons Attribution (CC BY) license (http://creativecommons.org/licenses/by/4.0/). 